\title{
1. Innovation and technological catch-up in the wine industry: an introduction
}

\author{
Elisa Giuliani, Andrea Morrison and \\ Roberta Rabellotti
}

\section{THE AIM OF THE BOOK}

Why choose the wine industry to investigate catching up in emerging countries? And why focus on science and innovation as the main drivers of catching up in a traditional agro-food industry such as wine? These two questions may well be asked by many potential readers of this book. Numerous recent studies about catching up are focused on countries such as China and India and on high-tech sectors such as electronics, software, pharmaceuticals and telecommunications. These cases are indeed globally known for having sparked economic growth in some selected locations, such as Bangalore in India or Shenzhen in China. Nevertheless, in spite of being in the spotlight, very little is known about the impact of these success stories on the rest of the country. Furthermore, there is little doubt that a large number of less developed countries are still highly dependent on agriculture and agro-food industries. The agro-food industry, though often depicted as low value added and with little innovation content, can instead represent a sector with significant opportunities of technological and rent upgrading. Hence, the real challenge is to understand how such sectors can contribute to the process of growth in these countries.

What has happened in the global wine industry is extremely interesting from a development point of view because the latecomers in the international market have radically changed how wine is produced, sold and consumed. Until the end of the 1980s, the international market for wine was dominated by European countries, and particularly by France and Italy. But since the beginning of the 1990s this supremacy has started to come under attack due to the spectacular performance, in terms of both exported volumes and values, of new international players. Among these new global leaders are affluent nations relatively new to the wine 
sector, such as the USA and Australia, and emerging economies, such as Argentina, Chile and South Africa.

The main argument supported in this book is that innovation in product and process, spurred by consistent investments and research efforts, has played a prominent role in the emergence of New World producers in the international market. Scientists have performed a key innovative role in the wine industry since the 1860s' phylloxera outbreak, but traditionally the production of good wines has been a privilege of a few terroir ${ }^{1}$ and a few producers, with the secrets transmitted from generation to generation. The empirical evidence collected in this book shows that New World producers have radically improved the quality of their wines, investing in research in universities and laboratories, strengthening the link between university and industry and importing external knowledge through experts. An investigation into the wine industry in countries such as Argentina, Chile and South Africa represents an extraordinary opportunity to show how a traditional agro-food industry can become highly competitive and catch up in the global market, when following a different trajectory from the long-standing leading countries, a new pathway in which innovation, science and research play a prominent role.

Therefore, the research questions in this book are as follows. What are the main conditions for successful catching up in the wine industry? Are scientific and technological knowledge, and institutions devoted to its production and diffusion, key ingredients for catching up? And if so, to what extent have New World countries developed indigenous technological and scientific capabilities? Were they able to enter the international scientific community successfully? Are there diverse catching-up trajectories emerging with the recent upsurge of New World countries? What can be learned from the successful case of the wine industry that can be extended to agrofood industries in general?

To answer these questions, a research project - Innovation and Globalization in the Wine Sector: An International Comparison between Argentina, Chile, Italy and South Africa - was carried out by the editors of this book, collecting new empirical evidence on wine firms, researchers in wine-related disciplines and industry-supporting institutions. To complement and enrich the findings of this project, some prominent scholars in the field were invited to contribute to the book. Some of these contributions were discussed in a workshop organized in 2009 at Università del Piemonte Orientale in Novara, Italy. The selected contributions are collected in this book, which is divided into two parts. In Part I, Chapters 2-4 adopt a macro-level perspective to analyze the process of catch-up in a variety of contexts (that is, both emerging and developed economies), with a focus on the role played by scientific research and innovation. Part II comprises a set 
of case studies on the main drivers of catch-up: universities and researchers, public institutions and firms, in Argentina, Chile and South Africa.

The book contributes to the existing knowledge in several ways. While contemporary accounts of catching up have mainly followed the high-tech fad (Malerba and Mani, 2009), here we shift the focus to the agro-food industry. We do so by providing fresh empirical evidence on places and countries that have seldom been at the centre of the analysis, but from which original and important lessons can be drawn. One such lesson is that beneath the surface of traditional industries there can be significant investments in knowledge-intensive activities, which create unique opportunities for catching up with leading countries. Moreover, the book challenges the conventional rhetoric about the backwardness of innovation systems in less developed countries, which are often thought to be plagued by few university-industry linkages and poor technological advancements on the side of domestic firms. In contrast, this research shows that in Argentina, Chile and South Africa, although at different levels of advancement, innovation systems, in which firms and other organizations have configured new inter-organizational relational models, have contributed significantly to the generation of higher-value products and new business opportunities. In the light of this, the empirical evidence collected in this book may be of relevance not only for scholars of innovation and development, but also for policy makers interested in understanding how to engage in catching up in the agro-food sectors.

This introductory chapter is organized as follows. Section 2 contains a discussion about the concept of catching up, which in our view goes beyond the idea of a unique path of convergence towards the leader, showing that latecomers can succeed by following different learning trajectories. In Section 3 we introduce the idea of an innovation system, which is discussed considering both a national perspective, in particular looking at the institutional difference between developed and emerging economies, and a sectoral one, which looks at the industry-specific commonalities across countries. Section 4 focuses on the role of science, universities and researchers within the wine system of innovation. We contend that building indigenous technological and scientific capabilities is a necessary requirement for latecomers that want to compete in international markets. Section 5 concludes with a presentation of the structure of the book.

\section{CATCHING UP: THEORY AND EXPERIENCES}

The concept of catching up has been commonly used in the economic literature to indicate the ability of a country to reduce income and productivity 
gaps with the leaders. In the earlier debate, catching up was straightforward: the larger the productivity gap between backward economies and the leaders, the higher the potential for the former to make a large leap. Therefore, backward countries were expected to grow more quickly than leaders, so that in the long run they would inevitably converge towards a similar per capita income. The above argument rests on the idea that latecomers can easily import technology and, through it, access and reap the benefits of international technological spillovers. In this view, catching up is considered to be a question of relative speed in a race along a fixed track, and technological learning is understood as a cumulative and linear process, which consists in copying the blueprint made by the leaders, rather than running in a new direction (Perez, 1986).

Since the end of the 1980s the spectacular performance of the newly industrializing countries (NICs) in Asia has encouraged novel conceptualizations of economic growth and structural change, given that the Asian experience could not be explained as the result of the import and adoption of technologies and organizational models developed in advanced countries, as implied by the theory of economic growth that prevailed in the 1950s and 1960s (Solow, 1956). There is a broad consensus in the literature that the progress of Asian NICs has involved significant deviations from earlier industrialization experiences, entailing distinctive strategic innovations, learning paths, accumulation of absorptive capacities and institutional building (Lall, 1992; Bell and Pavitt, 1993; Hobday, 1995; Kim, 1997; Altenburg et al., 2008).

According to the pioneering contribution by Abramovitz (1986), catch-up is a process going far beyond the mere adoption of new technologies, and depends on the ability of countries to build some 'technological congruence' with leaders as well as their own 'social capabilities'. The first concept indicates the conditions that latecomers need to share, at least to a certain degree, with leaders, in order to adopt their models. These might refer to economic factors such as market size, availability of inputs, consumer tastes, and so forth. The latter concept concerns issues such as technical competence as well as educational infrastructure, and more broadly those institutions supporting technological capabilities. In a similar vein, Nelson and colleagues have argued that catching-up countries need to master not only 'physical' technologies; they rather have to build 'social' technologies (Nelson and Sampat, 2001), which include 'organisational forms, bodies of law, public policies, codes of good business and administrative practice, customs norms' (Mazzoleni and Nelson, 2007: 1513).

All in all, the above-mentioned approaches clearly indicate that catching up is more than simply copying new technologies; it requires creative adaptation and innovation along and beyond the model followed by 
forerunners. Therefore, in their catching-up effort, latecomers do not simply follow the technological path of the advanced countries; they may skip some stages or even create their own individual path (Lee and Lim, 2001). Late entrants build on existing knowledge, but they would eventually depart from it by following their own trajectory of development. As suggested by Perez and Soete (1988), this occurs when windows of opportunity in the prevailing techno-economic paradigm (that is, the set of interrelated technical and organizational innovations that characterize the existing mode of production) open up. At such turning points, taking over is possible since incumbents are locked in existing technologies, management practices and labor skills. The burden of previous investments makes it difficult for them to fully recognize changes taking place in the external environment and endorse them. This eventually hampers the adoption of new technologies among leaders, which instead will diffuse more quickly elsewhere, in countries not bound to the old technology and the related institutional context. An excellent illustrative case comes from the history of economic development: the latecomer Germany developed its own way to industrialization based on the system of investment banks, and in so doing outpaced the UK in the early twentieth century. Similarly in the 1970s and 1980s, first Japan, then Korea and Taiwan, took over western economies in several high-tech sectors thanks to engineering excellence and government support (Mazzoleni and Nelson, 2007).

While much of the discussion on catching up has been carried out at the country level, there is also an interesting stream of literature extending this idea (or conceptualization) to sectors within and between national boundaries (Mytelka, 2004; Niosi and Reid, 2008; Malerba and Mani, 2009). In the chapters of this book, we investigate catching up and forging ahead in the wine industry, making the point that in this specific sector, the rise of latecomers in the global wine market, including some emerging countries (that is, Argentina, Chile and South Africa) has occurred thanks to significant discontinuities in both technologies and market demand. The discontinuities reflect the fact that in the 1980s to 1990s, new pathways for the production and marketing of wines have been explored by latecomer countries, which departed from the established business models of Old World countries, such as Italy and France. In other words, New World producers have prompted the process of technological modernization, product standardization and marketing innovation, which have proved to be in line with the requirements in the international market. More than that, these countries set the foundation for a new paradigm in the wine industry, based on a market-driven scientific approach to wine production. Such modernization has challenged Old World producers, and has had a remarkable impact not only on the industry knowledge base, but 
also on the relevant industry actors (for example, universities, regulatory bodies, companies) in both New and Old World producers.

\section{INNOVATION SYSTEMS AND CATCHING UP}

In the catching-up debate, the adoption of an innovation system perspective (Freeman, 1987; Lundvall, 1992; Edquist, 1997) has contributed to shifting the emphasis from resource endowments and comparative advantages to institutional variables, capabilities and the dynamic creation of competitive advantages. Focusing attention on innovation systems in development economics has followed from the realization of the need for conscious and purposive innovation effort and capacity building in less developed countries (Lundvall et al., 2009; Malerba and Mani, 2009). The burgeoning literature on innovation systems in less developed areas exemplifies the increased attention placed on the broad institutional set-up affecting learning as well as searching and exploring (Lundvall et al., 2009). As Nelson and Nelson (2002) emphasize, the innovation system idea is an institutional conception par excellence, articulated at the national, regional and local levels and characterized by the interaction of different actors - firms, universities, technology transfer organizations, service providers - as well as by frameworks and norms, set within relatively well-defined boundaries.

In less developed countries, where new frontier innovation is still scarcely generated and the bulk of knowledge and technology is imported, scholars have stressed the importance of extra-national influences on the innovation process, given that linkages with foreign firms and organizations play a central role in helping to operate innovation systems. The sectoral system approach (Malerba, 2004) complements the national and regional perspectives by underlying the transnational dimension of sectoral systems, that is, the role of international actors, linkages and transmission mechanisms, and the limits of national policies in the framework of increased global integration. In addition to the structuring of national and local innovation systems, inflows of knowledge and technology from external sources, as well as the dynamics of demand along the internationally fragmented chains of production, are essential components for upgrading and learning in emergent economies (Pietrobelli and Rabellotti, 2009).

State-of-the-art literature has therefore suggested that innovation systems in less developed countries are mainly learning systems and that connections outside national boundaries are crucial to acquire and absorb external knowledge (Viotti, 2002). These views have often been 
complemented by a widespread acknowledgment of the weaknesses of developing countries' innovation systems (for example, Intarakumnerd et al., 2002; Aubert, 2004). Nevertheless, this idea has recently been debated (Lundvall et al., 2009), and in this book we aim to contribute to the current debate by providing new empirical evidence about how firms and other organizations in the wine industry have in fact created successful innovation systems that have permitted the production of innovative and high-value products. We show that connections with global pipelines of technological knowledge have been significant in wine catch-up countries. Most of them run through international experts, such as consultant winemakers, and star scientists who play a role in spreading global knowledge on methods of production and ideas for product innovations in the domestic industry. Connections to consultants are common in advanced as well as in emerging countries' wine producers, showing that globalization in some instances has been an opportunity to access knowledge and technology rather than a threat for the latter countries. With regard to researchers, we show a rapidly increasing participation of catching-up countries in international research networks.

At the domestic level, the book illustrates how, in the new international context, old institutions, such as extension agencies, were forced to enter into a restructuring process, which transformed them into knowledge facilitators that enhance the formation of local social capital. At the country level, the growing engagement of public and private actors, often in partnership, has led to the development of supportive industrywide institutions. Remarkable examples can be found in some New World countries, such as South Africa and Australia, where two bodies funded by producer levies (respectively, Winetech and the Grape and Wine Research and Development Corporation) have contributed to creating public goods in the form of research and development (R\&D) promotion, and in so doing they have enhanced local wineries' innovation activity.

\section{INNOVATION SYSTEMS AND THE ROLE OF SCIENCE, UNIVERSITIES AND RESEARCHERS}

Within innovation systems, firms are the key actors in the innovation and learning processes, but an essential role is also played by other institutions and organizations and by the interactions taking place among them. The literature on innovation systems in less developed countries has mainly focused on the importance of organizations dealing with technology diffusion and extension, which have been considered as key in these contexts, given the nonexistence and/or the weakness of science and technology 
organizations (Lundvall et al., 2009). Nevertheless, in many developing countries increasing attention is being paid to the role that might be played by actors such as universities and public research organizations (PROs) - an awareness that stems from the strengthening of ties among science, technology and innovation in many industries - and also beyond those sectors traditionally defined as knowledge intensive. The contribution to economic development of science and research conducted at universities and PROs has been recognized by Mazzoleni and Nelson (2007) as one of the key elements of past and recent experiences of catching up.

Literature comparing the scientific and research productivity of advanced economies (for example, the USA versus Europe) as well as their institutional underpinnings has flourished in recent years, showing how different institutional contexts and policy models enable countries to reduce the gap with the frontier (Etzkowitz and Leydesdorff, 2000; Dosi et al., 2006). Instead, as pointed out by Mazzoleni (2008), a good understanding of the contribution and the functioning of research organizations in less developed countries is still far away. In fact, in backward countries it is widely disputed whether they should invest in tertiary education and whether universities and PROs should be encouraged to undertake advanced research. Nonetheless, it is less controversial that research organizations are necessary to support the development of indigenous capabilities and to build a national absorptive capacity (Albuquerque, 2004; Brundenius et al., 2009).

This is particularly true in the agricultural field where there is a need to undertake research and develop knowledge and technologies suited to the specific conditions of each country and region (Vessuri, 1990; Albuquerque, 2004). In agriculture, imported technologies need to be adapted to the local climate, soil conditions and other biophysical characteristics. Moreover, research issues addressed in temperate zones, where developed countries are generally located, are not necessarily the most relevant in tropical climates. A case in point is viticulture, where for example irrigation issues matter considerably more for wine growers in the South than for those in the North; similarly, plagues and viruses as well as soil conditions differ from country to country. This implies that accessing foreign sources of knowledge is important; nevertheless, in order to fully exploit the potential development of local crops and technology, it must be accompanied by investment in indigenous research, which can spur local technological capabilities and enhance both adoption and adaptation of international discoveries (Pardey and Beintema, 2001; Bernardes and Albuquerque, 2003; Giuliani, 2007). Furthermore, investing in indigenous capabilities is even more urgent today than it was in the past, as tighter international property rights regulations are restricting the opportunities 
for less developed countries to tap into international public knowledge (Mazzoleni and Nelson, 2007).

The wine sector represents a very interesting case in which to investigate whether the economic catch-up (if not forging ahead) is associated with a similar catch-up process in scientific capabilities. The evidence presented in this book clearly shows that New World countries are closing the gap with the established producers in terms of scientific research. First and foremost, national universities in catching-up countries are important generators of applied science, which is critical for the industry. Second, university researchers are not isolated but are part of a global knowledge network formed by academic scholars worldwide, who carry out research on wine-related topics, ranging from biotechnology to agronomics, chemistry and mechanical engineering. We show that scientists involved in wine-related research in the wine-producing latecomers have considerably expanded their participation in the international scientific community over the past 10 years: not only have they increased co-publications with peers in the Old World, but increasingly they have established research linkages with colleagues at universities in other New World countries. This evidence clearly points on the one hand to the growing importance of such countries as a source of scientific knowledge, and, more importantly, on the other it suggests that they are capable of setting their own research priorities and in doing so of influencing the international scientific agenda. Finally, we show that by tapping into international scientific knowledge, a few talented university researchers act as bridging agents and contribute to channelling international knowledge towards the domestic wine industry.

\section{THE STRUCTURE OF THE BOOK}

The book is structured in two parts. Part I investigates catching up undertaken by some New World producers, stressing the role played by scientific research and innovation in this process. Part II focuses on some of the main drivers of catch-up: universities and researchers, firms and supporting institutions.

In Chapter 2, Cusmano, Morrison and Rabellotti illustrate the significant discontinuities in both technologies and market demand that favored the emergence to the global stage of the New World producers. The interplay between national features and sector-specific dynamics, which emerges at the global level, is interpreted through the conceptual framework of the sectoral system of innovation (SSI) approach. The transformations that occurred in the wine industry are explained as a tale of co-evolution on the demand and supply sides, which has led to the 
emergence of a novel, knowledge-based, market-driven model, challenging the producer-driven approach of incumbents. The chapter shows that emerging countries with diverse institutional models and innovation strategies actively participate in the process of technological modernization and product standardization. These newcomers in the wine sector have responded particularly effectively to changes in demand, aligning emerging scientific approaches with institutional-building efforts and successful marketing strategies.

In Chapter 3, Cassi, Morrison and Rabellotti investigate the scientific performance, measured in terms of number of publications, of the successful latecomers in the global wine market. In addition, based on the analysis of co-authorships, the chapter explores to what extent the scientific wine community has become global, and in particular whether Argentina, Chile and South Africa undertake international linkages within the scientific and research system. Finally, analyzing the network of co-authorships, attention focuses on the structure of the national research systems in these three countries for highlighting the distinct roles played by PROs, universities and the industry in the existing domestic and international links.

In Chapter 4, Anderson focuses on Australia's wine industry, which has been through major structural changes over the past six decades and has grown especially rapidly since the early 1990s. Investments in generic promotion and in grape and wine R\&D have been significant features of the industry throughout that period, and have grown in importance following the formation in the early 1990s of the Australian Wine Export Council and the Grape and Wine R\&D Corporation, which coordinates the investing of grape grower and winemaker national levies and matching federal government funding. This chapter assesses the role that the innovation system has played in the industry's recent growth and concludes by speculating on the scope for more diversification and attention to regional diversities in the promotion and $\mathrm{R} \& \mathrm{D}$ strategies in the future of the Australian wine industry.

Part II investigates the main drivers of the catching-up process, and in Chapter 5 the focus is on universities in emerging regional innovation systems. According to Kunc and Tiffin, universities have the ability to understand existing technologies, maintain connections with external networks and are usually the main, if not the only, regional knowledge source. In order to fulfil their role, universities have to provide for a qualified workforce, locally adapted research, appropriate services and technologies for their regional stakeholders. The chapter proposes a set of measures for analyzing the involvement of universities in the development of their regional systems of innovation, applying it to investigate two universities located in two important wine regions in Argentina and Chile. 
The results suggest that the investigated wine regions follow two different development paths: in the case of Chile, exogenous sources of knowledge, such as foreign consultants, prevail with respect to those related to the local university, while in Argentina there are strong linkages between the university and the local companies, facilitating the circulation of knowledge from endogenous sources.

Chapter 6 focuses on the wine industry in Argentina, and McDermott and Corredoira examine a case regarding the institutional evolution of the country's wine industry. They show how the impressive catching-up process of the Mendoza wine industry is due to a large extent to a local institutional renovation, which has led to the emergence of a new generation of public-private institutions (PPIs). Because of their governance properties, the PPIs helped reshape both policy and inter-firm networks as well as improve firm access to a variety of knowledge resources. In turn, their unique survey data and statistical analysis suggest that firms improved their product upgrading because of the ways in which PPIs acted as social and knowledge bridges among previously isolated producer communities.

In Chapter 7, Giuliani and Rabellotti investigate the role that universities play in channeling international scientific knowledge into the Chilean and South African wine industries. Universities are critical actors for catching up and, within universities, the links of individual researchers with international research networks appear to be critical channels for directing external scientific knowledge into the local economy. The authors investigate the characteristics of such 'bridging researchers' and find that they are significantly more 'talented' than the average, both because they publish more in international journals and/or because they have received awards for their academic work. The authors suggest that this result may have significant policy implications, as policies aimed at strengthening the skills of these researchers should be welcomed in catching-up industries.

In Chapter 8, Lorentzen studies innovation in the wine industry of the Western Cape Province in South Africa. The focus of this chapter is on the nature and role of linkages between relevant actors in the wine sector as well as on the knowledge flows such interactions facilitate, in order to understand the relationship between the knowledge infrastructure and those linkages on the one hand and innovation on the other. It also raises the issue of spatial proximity, namely whether being close to one another is a necessary condition for such knowledge exchange. Finally, the question addressed is what, if anything, policy has to do with this being a success story.

In Chapter 9, Giuliani, Morrison and Rabellotti summarize the main findings of the book, drawing some lessons from the rich and varied 
empirical evidence collected. Skills, access to external knowledge, domestic research and innovation capability and networking between public and private actors are identified as the key drivers of the catching-up process successfully undertaken by some emerging countries in the wine sector. Finally, policy implications are discussed and an open agenda for future research is proposed.

\section{NOTE}

1. Terroir is a French term used to denote the special characteristics of an agricultural site, in terms of soil, weather conditions and farming techniques, each contributing to the unique qualities of the wine.

\section{REFERENCES}

Abramovitz, M. (1986), 'Catching up, forging ahead, and falling behind', Journal of Economic History, 46 (2), 385-406.

Albuquerque, E. (2004), 'Science and technology systems in less developed countries', in H. Moed, W. Glänzel and U. Schmoch (eds), Handbook of Quantitative Science and Technology Research, Dordrecht, the Netherlands: Kluwer Academic, pp. 759-78.

Altenburg, T., H. Schmitz and A. Stamm (2008), 'Breakthrough? China's and India's transition from production to innovation', World Development, 36 (2), 325-44.

Aubert, J.E. (2004), 'Promoting innovation in developing countries: a conceptual framework', World Bank, accessed September 2010 at http://info.worldbank. org/etools/docs/library/137729/0-3097AubertPaper\%5B1\%5D.pdf.

Bell, M. and K. Pavitt (1993), 'Technological accumulation and industrial growth: contrasts between developed and developing countries', Industrial and Corporate Change, 2 (2), 157-210.

Bernardes, A. and E.M. Albuquerque (2003), 'Cross-over, thresholds, and interactions between science and technology: lessons for less-developed countries', Research Policy, 32 (5), 867-87.

Brundenius C., B.-A. Lundvall and J. Sutz (2009), 'The role of universities in innovation systems in developing countries: developmental university systems empirical, analytical and normative perspectives', in B-A. Lundvall, K.J. Joseph, C. Chaminade and J. Vang (eds), Handbook of Innovation Systems and Developing Countries - Building Domestic Capabilities in a Global Setting, Cheltenham, UK and Northampton, MA, USA: Edward Elgar Publishing, pp. 311-33.

Dosi, G., P. Llerena and M. Sylos Labini (2006), 'The relationships between science, technologies and their industrial exploitation: an illustration through the myths and realities of the so-called "European Paradox", Research Policy, 35 (10), 1450-64.

Edquist, C. (ed.) (1997), Systems of Innovation: Technologies, Institutions and Organisations, London: Pinter. 
Etzkowitz, H. and L. Leydesdorff (2000), 'The dynamics of innovation: from national systems and "mode 2" to a triple helix of university-industrygovernment relations', Research Policy, 29 (2), 109-23.

Freeman, C. (1987), Technology Policy and Economic Performance: Lessons from Japan, London: Pinter.

Giuliani, E. (2007), 'The wine industry: persistence of tacit knowledge or increased codification? Some implications for catching-up countries', International Journal of Technology and Globalisation, 3 (2/3), 138-54.

Hobday, M. (1995), Innovation in East Asia: The Challenge to Japan, Aldershot and Brookfield, VT, USA: Edward Elgar.

Intarakumnerd, P., P. Chairatana and T. Tangchitpiboon (2002), 'National innovation system in less successful developing countries: the case of Thailand', Research Policy, 31 (8-9), 1445-57.

Kim, L. (1997), Imitation to Innovation: The Dynamics of Korea's Technological Learning, Boston, MA: Harvard Business School Press.

Lall, S. (1992), 'Technological capabilities and industrialization', World Development, 20 (2), 165-86.

Lee, K. and C. Lim (2001), 'Technological regimes, catching-up and leapfrogging: findings from the Korean industries', Research Policy, 30 (3), 459-83.

Lundvall, B.-A. (1992), National Systems of Innovation: Towards a Theory of Innovation and Interactive Learning, London: Pinter.

Lundvall, B.-A., K.J. Joseph, C. Chaminade and J. Vang (eds) (2009), Handbook of Innovation Systems and Developing Countries: Building Domestic Capabilities in a Global Setting, Cheltenham, UK and Northampton, MA, USA: Edward Elgar.

Malerba, F. (ed.) (2004), Sectoral Systems of Innovation: Concepts, Issues and Analyses of Six Major Sectors in Europe, Cambridge: Cambridge University Press.

Malerba, F. and S. Mani (eds) (2009), Sectoral Systems of Innovation and Production in Developing Countries: Actors, Structure and Evolution, Cheltenham, UK and Northampton, MA, USA: Edward Elgar.

Mazzoleni, R. (2008), 'Catching up and academic institutions: a comparative study of past national experiences', Journal of Development Studies, 44 (5), 678-700.

Mazzoleni, R. and R. Nelson (2007), 'Public research institutions and economic catch-up', Research Policy, 36 (10), 1512-28.

Mytelka, L. (2004), 'Catching up in new wave technologies', Oxford Development Studies, 3 (3), 389-405.

Nelson, R.R. and K. Nelson (2002), 'Technology, institutions, and innovation systems, Research Policy, 31 (2), 265-72.

Nelson, R.R. and B.N. Sampat (2001), 'Making sense of institutions as a factor shaping economic performance', Journal of Economic Behavior and Organization, 44 (1), 31-54.

Niosi, J. and S. Reid (2008), 'Biotechnology and nanotechnology: sciencebased enabling technologies as windows of opportunity for LDCs?', World Development, 35 (3), 426-38.

Pardey, P.G and N.M. Beintema (2001), Slow Magic: Agricultural R\&D a Century After Mendel, Washington, DC: International Food Policy Research Institute.

Perez, C. (1986), 'New technologies and development', in C. Freeman and B.-A. Lundvall (eds), Small Countries Facing the Technological Revolution, London: Pinter, pp. 85-97. 
Perez, C. and L. Soete (1988), 'Catching up in technology: entry barriers and windows of opportunity', in G. Dosi, C. Freeman, R.R. Nelson, G. Silverberg and L. Soete (eds), Technical Change and Economic Theory, London: Pinter, pp. 458-79.

Pietrobelli, C. and R. Rabellotti (2009), 'The global dimension of innovation systems - Linking innovation systems and global value chain', in B-A. Lundvall, K.J. Joseph, C. Chaminade and J. Vang (eds), (2009), Handbook of Innovation Systems and Developing Countries - Building Domestic Capabilities in a Global Setting, Cheltenham, UK and Northampton, MA, USA: Edward Elgar Publishing, pp. 214 40.

Solow, R.M. (1956), 'A contribution to the theory of economic growth', Quarterly Journal of Economics, 70, 65-4.

Vessuri, H.M.C. (1990), 'O inventamos o erramos: the power of science in Latin America', World Development, 18 (11), 1543-53.

Viotti, E.B. (2002), 'National learning systems: a new approach on technological change in late industrialising economies and evidence from the cases of Brazil and South Korea', Technological Forecasting \& Social Change, 69 (7), 653-80. 